\title{
Extraction and characterization of 6-shogaol and 6-gingerol from Zingiber officinale var.Bentong
}

\author{
${ }^{1,2}$ Sharizan, A. and ${ }^{2, *}$ Sahilah A.M. \\ ${ }^{1}$ Food Science and Technology Research Center, Malaysia Agricultural Research and Development Institute \\ (MARDI), Ibu Pejabat MARDI, Persiaran MARDI-UPM, 43400 Serdang, Selangor, Malaysia. \\ ${ }^{2}$ Department of Food Science, Faculty of Science and Technology, 43600 Bangi, Selangor, Malaysia
}

\author{
Article history: \\ Received: 5 February 2021 \\ Received in revised form: 4 \\ March 2021 \\ Accepted: 21 April 2021 \\ Available Online: 19 October \\ 2021
}

\section{Keywords:}

Bentong ginger,

Proximate analysis,

6-shogaol,

6-gingerol,

Antioxidant activity,

Nutraceutical food

DOI:

https://doi.org/10.26656/fr.2017.5(5).014

\begin{abstract}
Zingiber officinale Roscoe var. Bentong or locally known as Bentong ginger is exclusively planted and harvested in the district of Bentong, Pahang, Malaysia. The demand for this ginger species has dramatically increased due to its high food and medicinal values, owing to the presence of 6-shogaol and 6-gingerol as active compounds. This study aimed to measure the concentrations of those active compounds with respect to their one-year plantation duration (January - December 2018). The proximate analysis, heavy metals and antioxidant activity were simultaneously determined during the plant growth. 6-gingerol was present in both fresh and dried samples whilst 6-shogaol could only be found in dried samples. Fresh ginger recorded the highest 6-gingerol content (2.09 $\mathrm{mg} / \mathrm{g}$ ) in the seventh month of harvesting time. On the other hand, in the sixth month of harvesting time, dried ginger had the highest concentration of 6-gingerol $(0.66 \mathrm{mg} / \mathrm{g})$ and 6-shogaol $(1.85 \mathrm{mg} / \mathrm{g})$. Notably, the accumulation of heavy metals such as $\mathrm{As}, \mathrm{Pb}, \mathrm{Cd}$ and $\mathrm{Hg}$ in Bentong ginger was relatively low and within the permissible limit. Meanwhile, the total polyphenol and phenolic content of Bentong ginger extract solution were observed to decrease as the ginger was maturing. In conclusion, Z. officinale Roscoe var. Bentong yielded different amounts of active compounds with respect to its harvesting time. Nevertheless, it generally exhibits good values in terms of chemical compositions that can be potentially used as nutraceutical food.
\end{abstract}

\section{Introduction}

Ginger is widely used as a spice or flavouring agent in the food and beverage industry that includes daily consumption of dietary meals (Shivraj and Se-Won, 2015). In the medicinal aspect, ginger is one of the essential ingredients in folk medicine such as Chinese, Ayurveda and Greek since decades ago. It is traditionally used to treat flu fever, arthritis, gingivitis, stomachache, diarrhoea, asthma, constipation and diabetes (Malek et al., 2005; Arshad et al., 2014). Studies on the chemical composition of ginger disclose that ginger has many active compounds that possess antioxidant, antiinflammatory and potentially, antitumor properties (Shukla and Singh, 2007; Stoilova et al., 2007). Particularly, the rhizomes are reported to give significant anticancer, antimicrobial, antidiabetic and analgesic effects (Prabhakaran-Nair, 2013; Semwal et al., 2015; Srinivasan, 2017).

In Malaysia, Zingibe rofficinale Roscoe var. Bentong or commonly known as Bentong ginger is exclusive ginger that can only be found in the district of Bentong, Pahang. It is rich with amazing nutraceutical values that are characterized by the presence of bioactive groups of gingerol, zingiberine and shogaol. The amounts of secondary active compounds in Bentong ginger are mostly higher than local ginger, hence explaining its higher demand by many sectors. Generally, two main components in ginger are volatile compounds and nonvolatile oleoresin compounds. Volatile compounds consist of essential oils that give a pleasant odour to ginger. They are made up of monoterpenoids and hydrocarbon intermediates such as $\alpha$-zingiberene, arcurcumene, $\alpha$-farnesene, $\beta$-farnesene, linalool, gin-gerol, $\beta$-sesquiphellandrene, zingerone, dehydrogingerol and hexahydrocurcumin (Prabhakaran-Nair, 2013). Meanwhile, non-volatile compounds or oleoresins usually consist of phenolic groups such as gingerol, shogaol and zingerone that exhibit the spice flavour of ginger (Huang et al., 2012). Once extracted, the 
composition of oleoresins is usually in the range of 3$11 \%$, depending on the extraction method, location of plantation and state of rhizomes. In addition, other typical organic and inorganic groups can also be found in ginger, for example, ascorbic acid, manganese, sodium, chlorine, fatty acids and carbohydrate (PrabhakaranNair, 2013).

Gingerol group has been identified as the main active compound in fresh ginger. Its derivative, shogaol group can be detected in dried ginger, due to the degradation of gingerol from the thermal or acidic environment (Hans et al., 2005; Kubra and Rao, 2012). Reportedly, shogaol has a more distinct spice sensation and antioxidant activity than gingerol (Swarnalatha et al., 2010; Guo et al., 2014). In ginger rhizomes, there are several types of gingerol such as 4-gingerol, 8-gingerol, 10-gingerol and 12- gingerol. These compounds are thermally dependent as they form into shogaol structure that is less spicy but more aromatic than gingerol when exposed to high temperature. Progressively, they will be absent if the rhizomes are being dried or grilled (Semwal et al., 2015).

A number of analytical methods have been proposed to determine the concentration of 6-gingerol and 6shogaol including high-performance liquid chromatography (HPLC) and gas chromatography-mass spectrometry (GCMS) (El-Ghorab et al., 2010; Cheng et al.,2011; Yeah et al., 2014). HPLC analysis is preferred over GCMS to analyse both gingerol and shogaol groups as it is more thermal sensitive to hinder the conversion of gingerol into shogaol as a result of high temperature during GCMS analysis (Chen, 1986). The detection of these two compounds in ginger rhizomes has been successfully reported using HPLC analysis (Bailey-Shaw et al., 2008; Hans et al., 2015; Semwal et al., 2015).

The Malaysian government has prioritized the plantation project of Bentong ginger in the National Key Economic Area (NKEA \#EPP1) to promote economic growth in the local community. A few studies on Bentong ginger have been conducted but they are limited to the plantation practice, harvesting and selected phenolic compounds in matured species only (Ali et al., 2010; Ahmad et al., 2014; Tan et al., 2017; Lim and Wong, 2018). However, studies on the concentration of 6 -gingerol and 6-shogaol as active compounds in Bentong ginger and its optimum harvesting time have yet to be reported. Once identified, the findings are beneficial to farmers to plan the plantation and harvesting time according to the growth phase of Bentong ginger, while the consumers can expect the quality of Bentong ginger based on its chemical compositions that are time dependent. Besides, the pathway of secondary metabolites production in Bentong ginger can be better understood by recognizing the accumulation of 6gingerol and 6-shogaol in fresh and dried samples.

\section{Materials and methods}

\subsection{Sampling}

Raw samples of Bentong ginger (rhizomes) were collected from Kampong Janda Baik, Pahang, Malaysia according to pre-determined harvesting time in the third, sixth, seventh, eighth, ninth and twelfth months from January to December 2018. The samples were brought back to the laboratory to be cleaned by removal of soils, washing with distilled water, drying, grinding, and being stored in a closed vial at room temperature $\left(25^{\circ} \mathrm{C}\right)$ before further analysis.

\subsection{Preliminary analysis}

\subsubsection{Proximate analysis}

The proximate composition of Bentong ginger (i.e., moisture, ash, fat, protein, carbohydrate) was performed according to AOAC (1995). The moisture was determined by weighing $5 \mathrm{~g}$ of fresh rhizomes that had been ground beforehand, followed by drying at $105^{\circ} \mathrm{C}$ for $3 \mathrm{hrs}$. The dried sample was weighed. The moisture percentage was calculated based on the difference in sample weight before and after drying. To determine the ash content, about 5-10 g of rhizomes was placed in a crucible and heated up to $550^{\circ} \mathrm{C}$ to produce ash. After that, the ash was weighed to determine the ash percentage. The amount of fat and protein in the rhizome was calculated using the Soxhlet apparatus in petroleum ether solvent and Kjedahl micro method, respectively. Lastly, the carbohydrate content was obtained by calculating the total dried sample minus the weight of ash, fat and protein.

\subsubsection{Heavy metals content}

About $5 \mathrm{~g}$ of fresh sample was ground and weighed in a $250 \mathrm{~mL}$ conical flask. Next, $10 \mathrm{~mL}$ of concentrated nitric acid was added. The mixture was left at room temperature for $24 \mathrm{hrs}$ before being heated at $80^{\circ} \mathrm{C}$ for 5 hrs. The sample was left to cool at room temperature and later being diluted into $50 \mathrm{~mL}$ of solution. The concentrations of $\mathrm{As}, \mathrm{Cd}, \mathrm{Hg}$ and $\mathrm{Pb}$ were determined using inductively coupled plasma (ICP) (Perkin Elmer Optima, USA) (Tokalığlu et al., 2018).

\subsubsection{Total phenolic content}

The estimation of total phenolic content was performed using the Folin-Ciocalteu method (Shabanian et al., 2017). About $125 \mu \mathrm{L}$ of the ginger extract was added into a test tube with $500 \mu \mathrm{L}$ distilled water. After that, about $125 \mu \mathrm{L}$ Folin-Ciocalteu reagent was added and left for 6 mins. About $1.25 \mathrm{~mL}$ of $7 \%$ sodium 
carbonate was added with distilled water to obtain $3 \mathrm{~mL}$ of solution and left for another 90 mins. The absorbance value was determined using a UV-vis spectrometer at $750 \mathrm{~nm}$ with gallic acid as a standard solution $(0-450 \mu \mathrm{g} /$ $\mathrm{mL}$ ). The standard curve of gallic acid was used as a reference to calculate the total phenolic content in the sample. The procedures were conducted thrice to get the mean value for each sample.

\subsubsection{Free radical scavenging activity (DPPH)}

The free radical scavenging activity of ginger extract solution was measured using UV-vis spectrophotometer (Spectro UV-VIS Double Beam PC Scanning Spectrophotometer UVD 2950, Labomed Inc) at $517 \mathrm{~nm}$ absorbance (Ab) (Rosli- et al., 2018). Methanol solution containing DPPH was prepared prior to the analysis. A few ginger extract solutions were prepared at different concentrations $(40,80,120.160,200$ and $240 \mu \mathrm{g} / \mathrm{mL})$. About $1 \mathrm{~mL}$ of DPPH solution was added to each solution. The solution was then shaken using an orbital shaker continuously for $30 \mathrm{~min}$ at room temperature. Butylated hydroxyl toluene (BHT) acted as an antioxidant standard. This experiment was conducted thrice. The free radical scavenging activity (DPPH) was calculated using the formula as follows:

Free radical scavenging activity $(\mathrm{DPPH})=\mathrm{A} \mathrm{b}_{\text {standard }}-\frac{\mathrm{Ab_{ \text {sample } }}}{\mathrm{Ab_{ \text {standard } }}} \times 100$

where $A b_{\text {standard }}$ refers to the absorbance of standard solution and $A b_{\text {sample }}$ is the absorbance of sample solution.

\subsubsection{Ferric ion reducing antioxidant power assay}

The antioxidant activity can also be determined using the ferric ion reducing antioxidant power assay method (Mahdavi et al., 2017). About $1 \mathrm{~mL}$ of ginger extract solution with concentrations ranging from 40-40 $\mu \mathrm{g} / \mathrm{mL}$ was mixed with $25 \mathrm{~mL}$ of phosphate solution $(0.2$ $\mathrm{M}, \quad \mathrm{pH}$ 6.6) and $2.5 \mathrm{~mL}$ of $1 \%$ potassium hexacyanoferate. The mixture was incubated for $20 \mathrm{mins}$ at $25^{\circ} \mathrm{C}$. Next, about $2.5 \mathrm{~mL}$ of $10 \%$ trichloroacetic acid was added and the mixture was centrifuged for 20 mins at $3000 \mathrm{rpm}$. About $1 \mathrm{~mL}$ of the upper aliquot was used to mix with $2.5 \mathrm{~mL}$ of distilled water and $0.5 \mathrm{~mL}$ of $0.1 \% \mathrm{FeCl}_{2}$. The adsorption effect was measured using a UV-vis spectrophotometer at $700 \mathrm{~nm}$ with butylated hydroxyanisole (BHA) acted as a standard solution. All readings were performed thrice.

\subsection{Extraction of active compounds}

The analysis of 6-shogaol content was performed on the Bentong ginger samples that had been dried at $<50$ ${ }^{\circ} \mathrm{C}$ and the fresh samples according to Cho et al. (2015) with some modifications. All samples were ground into a fine powder and added to a $250 \mathrm{~mL}$ conical flask. About
$100 \mathrm{~mL}$ of methanol solution was added and shook for 2$5 \mathrm{hrs}$ using an orbital shaker. The extract solution was filtered using Whatman membrane filter 0.4 um prior to HPLC analysis.

\subsubsection{Standard solution preparation}

About $1 \mathrm{mg}$ of standard 6-gingerol and 6-shogaol (Sigma Aldrich) was dissolved in methanol HPLC grade solution in two separate flasks to prepare the standard solution with a known concentration of $2500 \mathrm{ppm}$. These standard solutions were then diluted into a series of solutions with concentrations of $150,200,250,300$ and $400 \mathrm{ppm}$ for 6-gingerol and 25, 50, 75, 100 and $150 \mathrm{ppm}$ for 6-shogaol.

\subsubsection{Chromatography and determination of 6- gingerol and 6-shogaol content}

HPLC (Shimadzu model Class VP, Japan) with a mobile phase of water (A) and acetonitrile (B) and stationary phase consisting of Waters Spherisorb $5 \mu \mathrm{m}$ ODS2 $(4.6 \times 150 \mathrm{~mm})$ separating column was employed to determine the 6-gingerol and 6-shogaol content in Bentong ginger. Photo iodide detector array was used at $230 \mathrm{~nm}$. The protocols for the mobile phase were as follows: from 0-20 mins, linear exchange of solution $\mathrm{A}$ from $70 \%$ to $10 \%$, followed by constant water content in stationary phase for the remaining 20-30 mins of analysis. The flow rate was fixed at $1 \mathrm{~mL} / \mathrm{min}$. About 10 $\mu \mathrm{L}$ pf sample was injected. Table 1 shows the composition of the mobile phase programme during

Table 1. Mobile phase composition in HPLC

\begin{tabular}{cccc}
\hline Time $(\mathrm{min})$ & $\begin{array}{c}\text { Flow rate } \\
(\mathrm{mL} / \mathrm{min})\end{array}$ & $\begin{array}{c}\text { Percentage of } \\
\text { water }(\%)\end{array}$ & $\begin{array}{c}\text { Percentage of } \\
\text { acetonitrile }(\%)\end{array}$ \\
\hline 0 & 1 & 70 & 30 \\
20 & 1 & 10 & 90 \\
30 & 1 & 10 & 90 \\
\hline
\end{tabular}

analysis.

\section{Results and discussion}

\subsection{Physical appearance of Bentong ginger}

Normally by practice, matured Bentong ginger is harvested in the fifth to sixth month after plantation. Commercially, in the seventh to the ninth month of the plantation, Bentong ginger is harvested to be marketed for its high fibre content and weight (1.8-3 kg). Figure 1 illustrates the appearances of Bentong ginger pertaining to harvesting time. During the first to the sixth month, the rhizomes had a small structure and were yellowish. Gradually, the size would be bigger, more fibrous and darker in yellow colour. However, in the eleventh and twelfth months of harvesting, the size shrunk to be smaller in size than previous progress. Usually, these kinds of rhizomes will be used for replanting purposes 


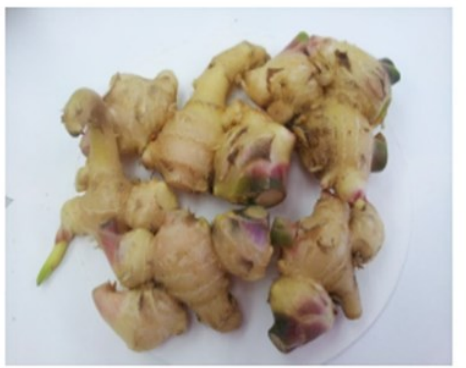

(a)

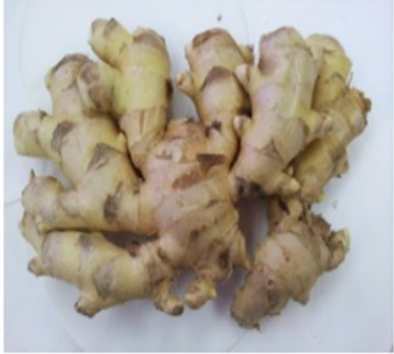

(b)

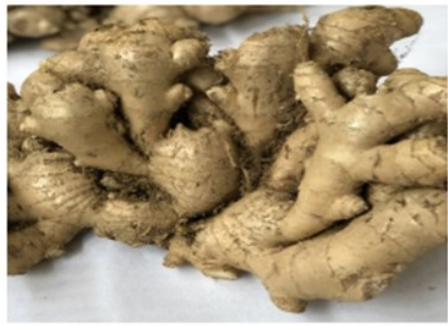

(c)

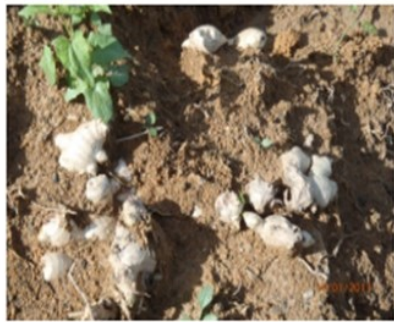

(d)

Figure 1. Physical appearances of Bentong ginger harvested in third (a) sixth (b) ninth (c) and twelfth month (d)

(League et al., 2006).

The cross-sectional area of Bentong ginger displayed a dark ring appearance that can be used to distinguish Bentong ginger from other species of ginger (Figure 2). This appearance was only visible earliest in the seventh month of harvesting time. Alternatively, this visual identification can be used to identify Bentong ginger

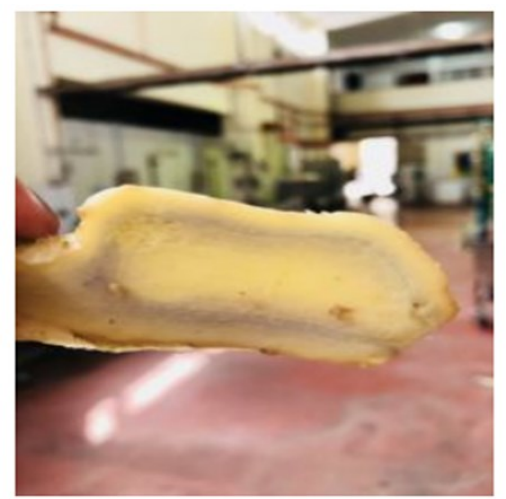

Figure 2. Dark ring appearance at the cross sectional area of Bentong ginger

other than spectrophotometry methods that list out the fingerprint chemicals for each ginger species.

\subsection{Proximate analysis}

Rhizomes in the seventh month of harvesting time were selected as samples for proximate analysis of

Table 2. Proximate analysis of Bentong ginger

\begin{tabular}{ccccc}
\hline $\begin{array}{c}\text { Ash content } \\
(\%)\end{array}$ & $\begin{array}{c}\text { Fat content } \\
(\%)\end{array}$ & $\begin{array}{c}\text { Protein } \\
\text { content } \\
(\%)\end{array}$ & $\begin{array}{c}\text { Moisture } \\
\text { content } \\
(\%)\end{array}$ & $\begin{array}{c}\text { Carbohydrate } \\
\text { content }(\%)\end{array}$ \\
\hline 1.45 & 0.54 & 1.74 & 88.57 & 7.71 \\
\hline
\end{tabular}

Bentong ginger, as tabulated in Table 2. The content for ash, fat, moisture, protein and carbohydrate in Bentong ginger was $1.4,0.54,1.74,88.57$ and $7.71 \%$ respectively. Similarly, El Ghorab et al. (2010) reported $88.5 \%$ of moisture in their South Australia ginger. The relative moisture in ginger is commonly in the range of $79-90 \%$ that is typically influenced by weather and its storage manner.

\subsection{Heavy metals content}

Table 3. Heavy metals content in Bentong ginger

\begin{tabular}{cc}
\hline Heavy metals & Concentration $(\mathrm{mg} / \mathrm{kg})$ \\
\hline $\mathrm{As}$ & undetected \\
$\mathrm{Pb}$ & 1.55 \\
$\mathrm{Cd}$ & 0.22 \\
$\mathrm{Hg}$ & 0.003 \\
\hline
\end{tabular}

Table 3 lists the heavy metals content $(\mathrm{As}, \mathrm{Pb}, \mathrm{Cd}$ and $\mathrm{Hg}$ ) in Bentong ginger. Heavy metals analysis detected $1.55,0.22$ and $0.003 \mathrm{mg} / \mathrm{kg}$ of $\mathrm{Pb}, \mathrm{Cd}$, and $\mathrm{Hg}$ respectively. The accumulation of these heavy metals was relatively low and considered safe to consume according to the Food and Drug Administration (FDA) agency. The presence of selected heavy metals might originate from the fertilizing activity on the soils (Saod et al., 2019).

\subsection{Total phenolic content and antioxidant activity}

Selected Bentong ginger samples from the seventh, eighth and ninth of harvesting time were tested for their total phenolic content and antioxidant activity as can be seen in Table 4. Interestingly, the total phenolic content showed a synergistic effect with the antioxidant activity, as a higher amount of total phenolic content would promote higher antioxidant activity. Similar findings were reported by Maizura et al. (2011) that found a significant correlation between total phenolic content and antioxidant activity in all of their samples, namely kesum, ginger and turmeric. The reduction of those compounds with harvesting time can be associated with the maturity of ginger that contained less phenolic content (Ghasemzadeh et al., 2010).

\subsection{Determination of 6-gingerol and 6-shogaol}

Table 4. Total phenolic content and antioxidant activity of Bentong ginger

\begin{tabular}{cccc}
\hline $\begin{array}{c}\text { Harvesting time } \\
(\text { month })\end{array}$ & $\begin{array}{c}\text { Polyphenol content } \\
(\mathrm{mg} \text { GAE/100 } \mathrm{g})\end{array}$ & $\begin{array}{c}\text { Total phenolic content } \\
(\mathrm{mg} \mathrm{CE} / 100 \mathrm{~g})\end{array}$ & $\begin{array}{c}\text { DPPH scavenging activity } \\
(\% \text { inhibition })\end{array}$ \\
\hline 7 & 940.87 & 204.49 & 75.99 \\
8 & 871.78 & 191.41 & 77.23 \\
9 & 803.38 & 170.05 & 73.33 \\
\hline
\end{tabular}


The content of 6-gingerol and 6-shogaol in all samples was determined using HPLC-PDA spectrophotometry based on the comparison of chromatograms of samples with standards of 6-gingerol and 6-shogaol, as can be seen in Figure 3. As a result, 6gingerol and 6-shogaol were detected at retention time of $11.82 \mathrm{~min}$ and $16.36 \mathrm{~min}$, respectively. As illustrated, 6shogaol was detectable only in dried Bentong ginger. Meanwhile, 6-gingerol could be found in both fresh and dried Bentong ginger. Previous studies confirm that 6shogaol is present when 6-gingerol undergoes dehydration process from thermal effect or long period of storage (Ko et al., 2019).

Figure 4 shows the UV-vis spectra for the identification of active compounds in the range of 200$800 \mathrm{~nm}$. Two wavelength peaks can be used as a reference to determine the active compounds in ginger (226 and $282 \mathrm{~nm}$ ). The $230 \mathrm{~nm}$ wavelength was set as a reference in this study. This absorbance pattern was in agreement with the findings by Kubra et al., (2012) that investigated the absorbance spectra of active compounds of the gingerol group.

Meanwhile, Figure 5 displays the calibration curve for the standard solution of 6-gingerol and 6-shogaol. The correlation coefficients for both data exceeded 0.99 , thus signifying good linear regression between HPLC data and concentration of a standard solution. On the other hand, Figure 6 compares the 6-gingerol content in fresh rhizomes of ginger varieties. Bentong ginger recorded the highest 6-gingerol $(2.4660 \mathrm{mg})$ when compared with Chinese ginger $(0.2021 \mathrm{mg})$, Tambunan ginger $(0.4963 \mathrm{mg})$, fertigated ginger $(0.7404 \mathrm{mg} / \mathrm{g})$,

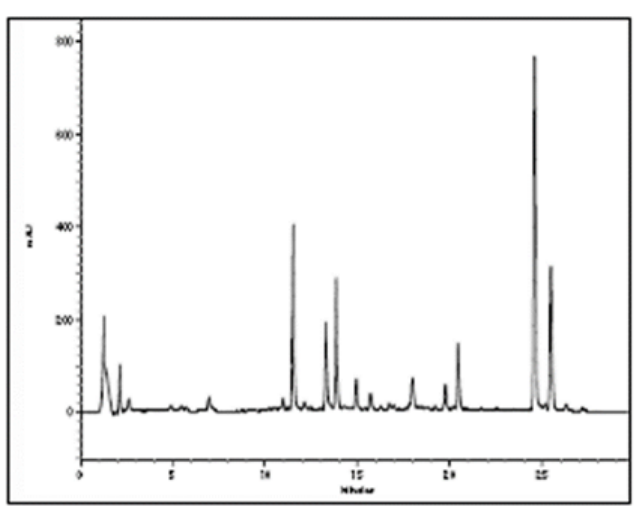

(b)

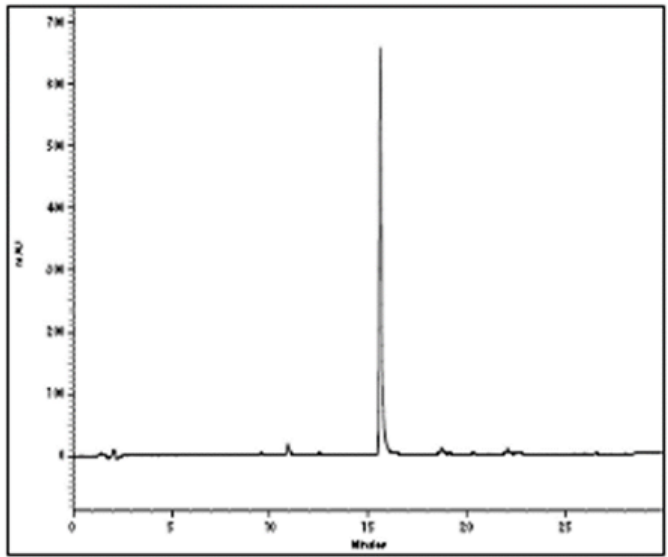

(c)

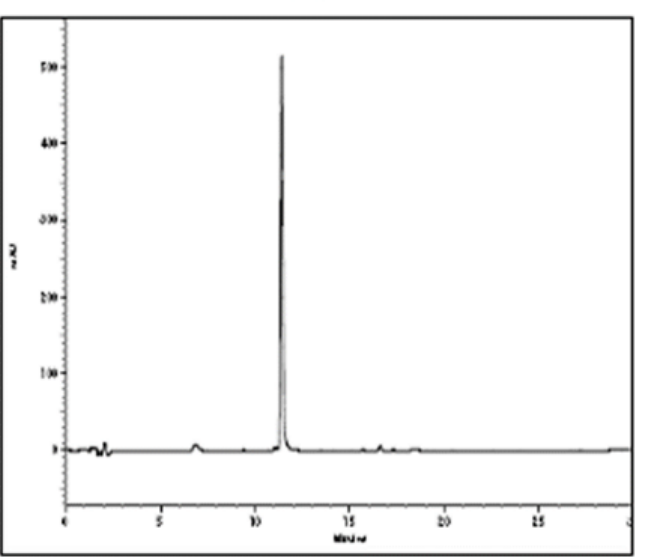

(d)

Figure 3. Chromatograms of Fresh Rhizomes (a) Dried Rhizomes (b) Standard 6-gingerol and (c) Standard 6-shogaol (d)

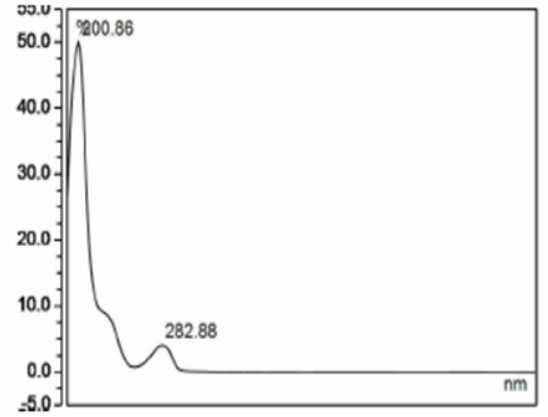

(a)

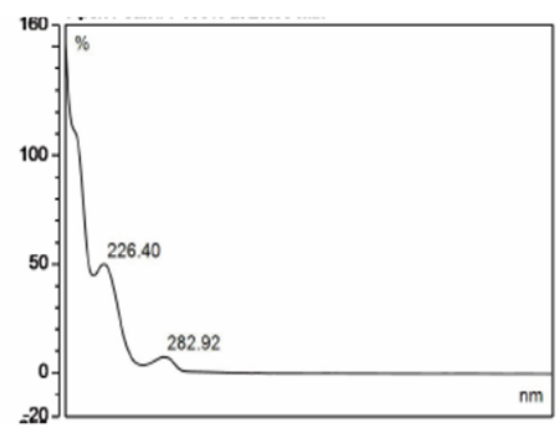

(b)

Figure 4. UV-vis Spectra for (a) 6-gingerol and (b) 6-shogaol 
Calibration curve of standard 6-gingerol

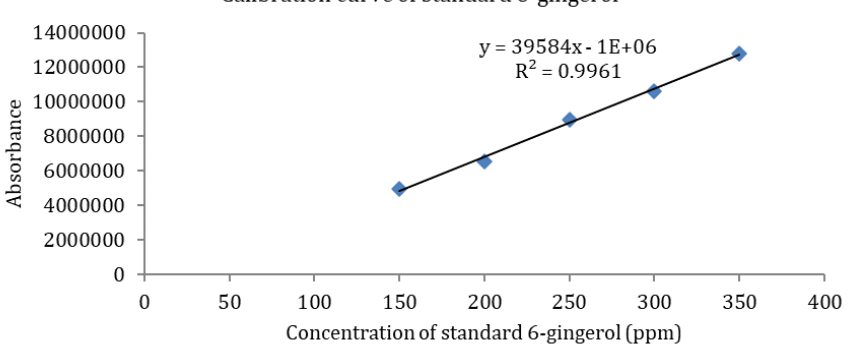

Calibration curve of standard 6-shogaol

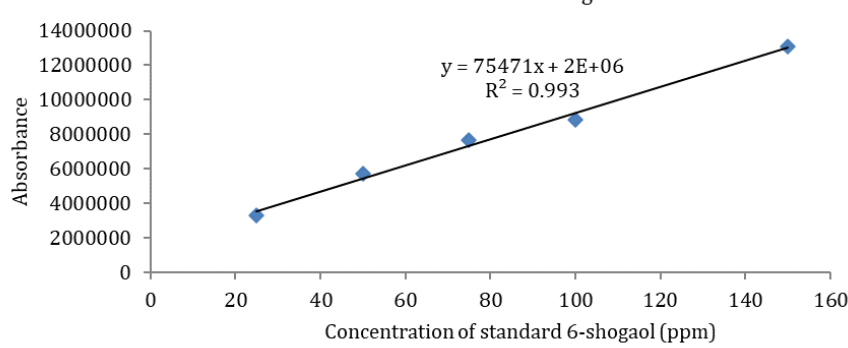

Figure 5. Calibration Curve for 6-gingerol and 6-shogaol

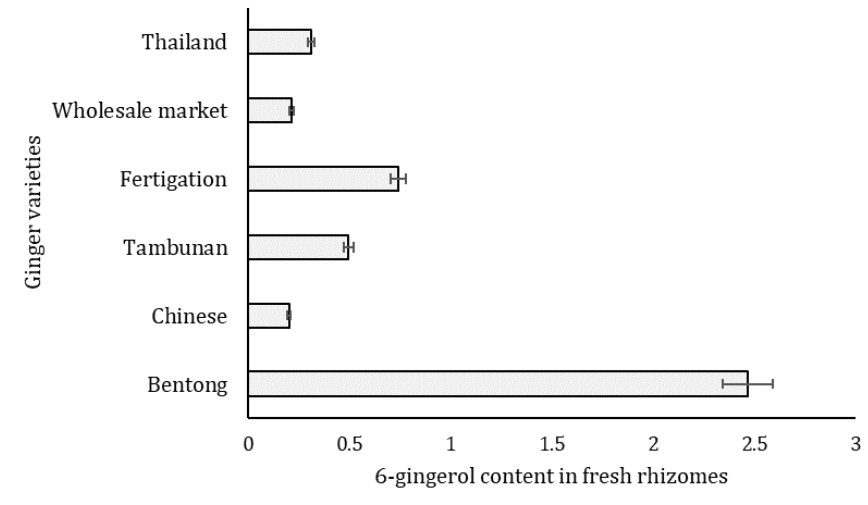

Figure 6. Comparison of 6-gingerol content among fresh ginger varieties

wholesale market ginger $(0.2163 \mathrm{mg} / \mathrm{g})$ and Thailand ginger $(0.3102 \mathrm{mg} / \mathrm{g})$. This information has further highlighted the speciality of Bentong ginger that is rich in 6-gingerol for nutraceutical value.

The content of 6-gingerol and 6-shogaol in fresh and dried Bentong ginger is compared in Table 5. In fresh rhizomes, the highest amount of 6-gingerol was 2.0833 $\mathrm{mg} / \mathrm{g}$ in the seventh month of harvesting time. Meanwhile, the highest amount of 6-gingerol and 6shogaol in dried Bentong ginger was 0.6653 and 1.8504 $\mathrm{mg} / \mathrm{g}$, respectively in the sixth month of harvesting time. Srinivasan et al. (2019) reported similar trend of 6gingerol and 6-shogaol concentrations in their ginger. The decrease in the amount of those active compounds can be explained by the maturity of ginger that forms more fibrous structure with increasing harvesting time.

\section{Conclusion}

The amount of 6-gingerol and 6-shogaol as active compounds in Bentong ginger has been successfully determined using HPLC method. Our findings discovered that Bentong ginger had the highest 6gingerol content among other varieties of ginger that demonstrates the speciality of Bentong ginger. In addition, 6-shogaol was only found in dried samples. The active compounds were found to be time-dependent as their optimum content was in the sixth and seventh month of harvesting time, for fresh and dried Bentong ginger, respectively. Future studies on Bentong ginger should highlight another parameter that influences the concentrations of these active compounds, for instance, extraction methods. Besides, other active compounds in the volatile component of ginger can be further explored.

\section{Conflict of interest}

The authors declare no conflict of interest.

\section{Acknowledgements}

The authors would like to acknowledge Universiti Kebangsaan Malaysia (UKM) and Malaysia Agricultural Research and Development Institute (MARDI) for the instrument facilities.

\section{References}

Ahmad, N., Foo, H.L., Jamilah, B. and Hasanah, M.G. (2014). Partial characterization of an enzymatic extract from Bentong ginger (Zingiber officinale var. Bentong). Molecules, 19(8), 12336-12348. https:// doi.org/10.3390/molecules190812336

Ali, G., Hawa, Z.E.J. and Asmah, R. (2010). Antioxidant activities, total phenolics and flavonoids content in

Table 5. Comparison of 6-gingerol and 6-shogaol content in fresh and dried rhizomes of Bentong ginger

\begin{tabular}{ccccc}
\hline \multirow{2}{*}{$\begin{array}{c}\text { Harvesting time } \\
\text { (month) }\end{array}$} & \multicolumn{2}{c}{ Fresh rhizomes } & \multicolumn{2}{c}{ Dried rhizomes } \\
\cline { 2 - 5 } & 6-gingerol $(\mathrm{mg} / \mathrm{g})$ & 6-shogaol $(\mathrm{mg} / \mathrm{g})$ & 6-gingerol $(\mathrm{mg} / \mathrm{g})$ & 6-shogaol $(\mathrm{mg} / \mathrm{g})$ \\
\hline 3 & $0.1355 \pm 0.0205$ & $\mathrm{ND}$ & $0.2378 \pm 0.0181$ & $0.9120 \pm 0.0936$ \\
6 & $1.9263 \pm 0.0775$ & $\mathrm{ND}$ & $0.6653 \pm 0.1467$ & $1.8504 \pm 0.2030$ \\
7 & $2.0883 \pm 0.1811$ & $\mathrm{ND}$ & $0.3417 \pm 0.0380$ & $1.5456 \pm 0.1077$ \\
8 & $1.6126 \pm 0.0295$ & $\mathrm{ND}$ & $0.2956 \pm 0.0325$ & $1.5021 \pm 0.1494$ \\
9 & $0.8611 \pm 0.0257$ & $\mathrm{ND}$ & $0.4960 \pm 0.0203$ & $0.9631 \pm 0.0931$ \\
12 & $0.5188 \pm 0.1534$ & $\mathrm{ND}$ & $0.3185 \pm 0.3979$ & $0.7704 \pm 0.0386$ \\
\hline
\end{tabular}

ND: Not Detected 
two varieties of Malaysia young ginger (Zingiber officinale Roscoe). Molecules, 15(6), 4324-4333. https://doi.org/10.3390/molecules 15064324

AOAC. (1995). Official Methods of Analysis. $16^{\text {th }}$ ed. Washington, DC, USA: Association of Official Analytical Chemists.

Arshad, H.R, Fahad, M.A. and Salah, M.A. (2014). Active ingredients of ginger as potential candidates in the prevention and treatment of diseases via modulation of biological activities. International Journal of Physiology, Pathophysiology and Pharmacology, 6(2), 125-136.

Bailey-Shaw, Y.A., Williams, L.A.D., Junor, G., Green, C., Hibbert, S.L., Salmon, C.A. and Smith, A.M. (2008). Changes in the contents of oleoresin and pungent bioactive principles of Jamaican ginger (Zingiber officinale Roscoe) during maturation. Journal of Agricultural and Food Chemistry, 56(14), 5564-5571. https://doi.org/10.1021/jf072782m

Chen, C. (1986). Chromatographic analyses of gingerol compounds in ginger (Zingiber officinale) extracted by liquid carbon dioxide. Journal of Chromatography, 360, 163-173. https:// doi.org/10.1016/S0021-9673(00)91659-5

Cheng, X., Liu, Q., Peng, Y., Qi, L. and Li, P. (2011). Steamed ginger (Zingiber officinale): Changed chemical profile and increased anticancer potential. Food Chemistry, 129(4), 1785-1792. https:// doi.org/10.1016/j.foodchem.2011.06.026

Cho, S., Lee, D.G., Lee, S., Chae, S. and Lee, S. (2015). Analysis of the 6-gingerol content in Zingiber species and their commercial foods using HPLC. Journal of Applied Biological Chemistry, 58(4), 377 -381. https://doi.org/10.3839/jabc.2015.059

El-Ghorab, A.H., Nauman, M., Anjum, F.M., Hussain, S. and Nadeem, M. (2010). A comparative study on chemical composition and antioxidant activity of ginger (Zingiber officinale) and cumin (Cuminumcyminum). Journal of Agricultural and Food Chemistry, 58(14), 8231-8237. https:// doi.org/10.1021/jf101202x

Ghasemzadeh, A., Jaafar, H.Z.E. and Rahmat, A. (2010). Antioxidant activities, total phenolics and flavonoids content in two varieties of Malaysia young ginger (Zingiber officinale Roscoe). Molecules, 15(6), 4324 -4333. https://doi.org/10.3390/molecules 15064324

Guo, J., Wu, H., Du, L., Zhang, W. and Yang, J. (2014). Comparative antioxidant properties of some gingerols and shogaols, and the relationship of their contents with the antioxidant potencies of fresh and dried ginger (Zingiber officinale Roscoe). Journal of Agricultural Science and Technology, 16(5), 1063-
1072.

Hans, W., David, N.L., Mike, K.S. and Stephen, P.M. (2005). Gingerol content of diploid and teraploid clones of ginger (Zingiber officinale Roscoe). Journal of Agricultural and Food Chemistry, 53(14), 5772 - 5778. https://doi.org/10.1021/jf050435b

Huang, B., Wang, G., Chu, Z. and Qin, L. (2012). Effect of oven drying, microwave drying, and silica gel drying methods on the volatile components of ginger (Zingiber officinale Roscoe) by HS-SPME-GC-MS. Drying Technology: An International Journal, 30(3), 248-255.

doi.org/10.1080/07373937.2011.634976

https://

Ko, M.-J., Nam, H.H. and Chung, M.-S. (2019). Conversion of 6-gingerol to 6-shogaol in ginger (Zingiber officinale) pulp and peel during subcritical water extraction. Food Chemistry, 270, 149-155. https://doi.org/10.1016/j.foodchem.2018.07.078

Kubra, I.R and Rao, L.J. (2012). An impression on current developments in the technology, chemistry, and biological activities of ginger (Zingiber officinale Roscoe). Critical Reviews in Food Science and Nutrition, 52(8), 651-688. https:// doi.org/10.1080/10408398.2010.505689

League, M.T., Colbert, E.P., Seliskar, D.M. and Gallagher, J.L. (2006). Rhizome growth dynamics of native and exotic haplotypes of Phragmites australis (common reed). Estuaries and Coasts, 29(2), 269276. https://doi.org/10.1007/BF02781995

Lim, W.Y. and Wong, C.W. (2018). Inhibitory effect of chemical and natural anti-browning agents on polyphenol oxidase from ginger (Zingiber officinale Roscoe). Journal of Food Science and Technology 55(8), 3001-3007. https://doi.org/10.1007/s13197018-3218-7

Mahdavi, B., Yaacob, W.A. and Din, L.B. (2017). Antioxidant and antimicrobial activity of the extracts from different parts of Etlingera sayapensis (Zingiberaceae). Sains Malaysiana, 46(9), 15651571. https://doi.org/10.17576/jsm-2017-4609-27

Maizura, M., Aminah, A. and Wan Aida, W.M. (2011). Total phenolic content and antioxidant activity of kesum (Polygonum minus), ginger (Zingiber officinale) and turmeric (Curcuma longa) extract. International Food Research Journal, 18, 526-531.

Malek, S.R.A., Ibrahim, H., Hong, S.L, Lee, G.S, Chan, K.S and Ali, N.A.M. (2005). The essential oils of Zingiber officinale variants. Malaysian Journal of Science, 24(2), 37-43.

Prabhakaran-Nair, K.P. (2013). The Agronomy and Economy of Turmeric and Ginger: The Invaluable Medicinal Spice Crops. Atlanta, USA: Elsevier Inc. 
Rosli, M.A.F., Azizan, K.A. and Goh, H. (2018). Antioxidant activity of pitcher extracts from three nepenthes species. Sains Malaysiana, 47(12), 30693075. https://doi.org/10.17576/jsm-2018-4712-17

Saod, W.M., Zaidan, T.A. and Al-Rawi, A.S. (2019). Estimation of selected essential metals in ginger (Zingiber officinale) and roselle (Hibiscus sabdariffa). Journal of University of Anbar for Pure Science, 13(1), 24-27.

Semwal, R.B., Semwal, D.K., Combrinck, S. and Viljoen, A.M. (2015). Gingerols and shogaols: important nutraceutical principles from ginger. Phytochemistry, 117, 554-568. https:// doi.org/10.1016/j.phytochem.2015.07.012

Shabanian, S., Khalili, S., Lorigooini, Z., Malekpour, A. and Heidari-Soureshjani, S. (2017). The effect of vaginal cream containing ginger in users of clotrimazole vaginal cream on vaginal candidiasis. Journal of Advanced Pharmaceutical Technology and Research, 8(2), 80-84.

Shivraj, H.N. and Se-Won, P. (2015). Chromatographic analysis, antioxidant, anti-inflammatory, and xanthine oxidase inhibitory activities of ginger extracts and its reference compounds. Industrial Crops and Products, 70, 238-244. https:// doi.org/10.1016/j.indcrop.2015.03.033

Shukla, Y. and Singh, M. (2007). Cancer preventive properties of ginger: a brief review. Food and Chemical Toxicology, 45(5), 683-90. https:// doi.org/10.1016/j.fct.2006.11.002

Srinivasan, K. (2017). Ginger rhizomes (Zingiber officinale): A spice with multiple health beneficial potentials. Pharma Nutrition, 5(1), 18-28. https:// doi.org/10.1016/j.phanu.2017.01.001

Srinivasan, V., Thankamani, C.K., Dinesh, R., Kandiannan, K., Hamza, S., Leela, N.K., Zachariah, T.J. (2019). Variations in soil properties, rhizome yield and quality as influenced by different nutrient management schedules in rainfed ginger. Agricultural Research, 8(2), 218-230. https:// doi.org/10.1007/s40003-018-0382-y

Stoilova, I., Krastanov, A., Stoyanova, A., Denev, P. and Gargova, S. (2007). Antioxidant activity of a ginger extract (Zingiber officinale). Food Chemistry, 102 (3), 764-770. https://doi.org/10.1016/ j.foodchem.2006.06.023

Swarnalatha, D., Mallikarjuna, R.P., Vishna, D.N., Madhu, K.B., Satyanarayana, T.J. and Narsimha, K. (2010). Comparative antioxidant and antiinflammatory effects of 6-gingerol, 8-gingerol, 10gingerol and 6-shogaol. Journal of Ethnopharmacology, 127(2), 515-520. https:// doi.org/10.1016/j.jep.2009.10.004

Tan, X.Y, Siti Hajar, A, Nur Indah, A.S, Nazamid, S. and Mohd Firdaus, I. (2017). Postharvest quality of chilling injured ginger rhizomes (Zingiber officinale Roscoe $\mathrm{Cv}$. Bentong) as affected by maturity stages, storage temperatures, and durations. Indian Journal of Applied Research, 7(4), 595-601.

Tokalıoğlu, Ş., Çiçek, B., İnanç, N., Zararsız, G. and Öztürk, A. (2018). Multivariate statistical analysis of data and ICP-MS determination of heavy metals in different brands of spices consumed in Kayseri, Turkey. Food Analytical Methods, 11(9), 24072418. https://doi.org/10.1007/s12161-018-1209-y 